\title{
Urinary cyclic adenosine monophosphate in young adults and elderly subjects ${ }^{1}$
}

\author{
CARLO GENNARI, MARCO GALLI, AND MARIO MONTAGNANI
}

From the Institute of Medical Pathology, University of Siena, Italy

SYNOPSIS The 24-hour urinary excretion of cyclic 3',5'-adenosine monophosphate (cAMP) was measured by a protein-binding assay in 55 healthy volunteers (aged 20-35 yr) and in 30 hospitalized elderly subjects (aged 70-93 yr). In the older subjects the mean 24-hour cAMP excretion was significantly lower; the correlation between cAMP excretion and age demonstrated a progressive decrease from the age of 70 to the tenth decade. Many different factors could account for the reduced urinary cAMP excretion in elderly subjects: a decline in the reactivity of the adenyl cyclase-cAMP system related to physiological ageing; reduced physical activity; a reduction in the glomerular filtration rate or decreased production of cAMP by tubular cells in the senile kidney.

Following the demonstration that cyclic $3^{\prime}, 5^{\prime}$ adenosine monophosphate (cAMP) appears in urine (Butcher and Sutherland, 1962), several investigators sought to explain its origin and significance. Exercise (Eccleston et al, 1970), upright posture (Hamet et al, 1973), pregnancy (Taylor et al, 1970), glucagon (Broadus et al, 1970b), vasopressin (Takahashi et al, 1966; Chase and Aurbach, 1967), catecholamines (Ball et al, 1972), and parathyroid hormone (Chase and Aurbach, 1967; Kaminsky et $a l, 1970$; Taylor et al, 1970) influence the urinary excretion of cAMP. Support for the kidney as the tissue of origin of the increased urinary cAMP excretion has come only from studies on the renal action of parathyroid hormone and vasopressin (Chase and Aurbach, 1968). The demonstration of increased urinary cAMP excretion in hyperparathyroid patients led to the investigation of the clinical usefulness of this test in the differential diagnosis of hypercalcaemic states (Murad and Pak, 1972; Neelon et al, 1973; Mallette et al, 1974). As it concerns normal subjects, the 24-hour urinary excretion of cAMP has been evaluated in adults and children (Linarelli, 1972). Apart from these observations, we know of no systematic study of the effect of age on the urinary excretion of cAMP. We report here 24-hour urinary cAMP data for men and women from the third to the tenth decades of life.

${ }^{1}$ This work was supported by CNR grant no. 73.00497/04.

Received for publication 7 July 1975.

\section{Methods}

The 24-hour urinary excretion of cAMP was determined in 55 healthy volunteers aged 20-35 years, mostly university students, who were unrestricted in regard to diet and activity, and in 30 hospitalized subjects aged 70-93 years without symptoms or history of peptic-ulcer disease, hypercalcaemia, bone disease, renal stones, renal insufficiency, essential hypertension or diabetes.

Twenty-four-hour urines beginning at 0800 were collected under refrigeration. At the end of the urine collection periods aliquots of urine were frozen at $-20^{\circ} \mathrm{C}$ until analysed for cAMP and creatinine content. Fifteen of the younger subjects had sequential 24-hour urines collected on several days.

A $50 \mu \mathrm{l}$ aliquot from each sample was assayed by the 'cyclic AMP assay kit' of the Radiochemical Centre, Amersham, UK. The cyclic AMP assay is based on the competition between unlabelled cyclic AMP and a fixed quantity of the tritium-labelled compound for binding to a protein which has a high specificity and affinity for cyclic AMP; the method has been described in detail by Tovey et al (1974).

\section{Results}

The mean 24-hour urinary cAMP excretions in young adults and elderly subjects are shown in fig 1. Normal young adults excreted 3.61 \pm 0.19 SEM $\mu \mathrm{mol}$ daily; by contrast, in elderly subjects the mean 24-hour cAMP excretion was significantly 
CAMP

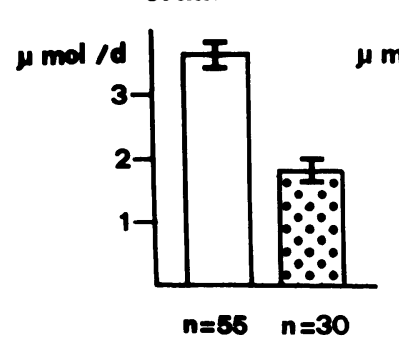

Fig 1 Mean (+ SEM) 24-hour urinary cAMP excretion (left) and cAMP-creatinine ratio (right) in a group of 55 normal adults (20-35 yr) and in 30 elderly subjects $(70-93 \mathrm{yr})$.

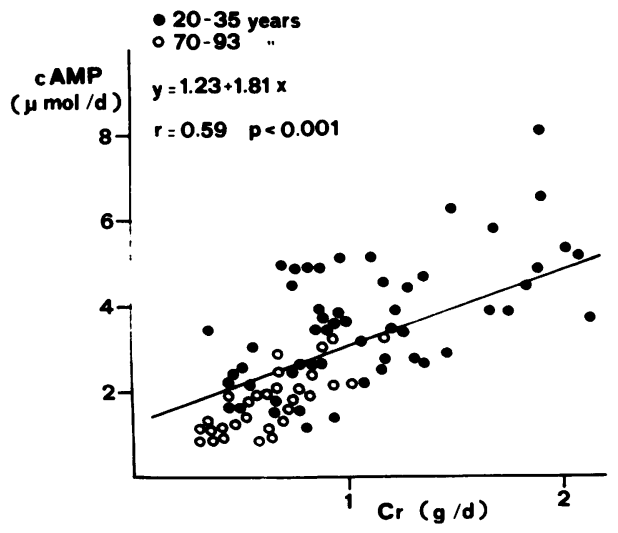

Fig 2 Plot of cAMP excretion ( $\mu$ mol/day) against creatinine excretion ( $g /$ day) in 55 normal young adults (20-35 yr) and in 30 elderly subjects (70-93 yr).

lower: $1.78 \pm 0.12$ SEM $\mu \mathrm{mol}$ daily $(\mathrm{P}<0.001)$. Expressing these levels in relation to the quantity of creatinine that was concomitantly excreted, the difference between the two groups was reduced: in young subjects the mean cAMP-creatinine ratio $(\mu \mathrm{mol} / \mathrm{g})$ was $3.73 \pm 0.20 \mathrm{SEM}$ in older subjects $2.79 \pm 0.10$ SEM $(P<0.01)$. A plot of the cAMP excretion per 24 hours against excretion per gram creatinine (fig 2 ) showed a highly significant correlation in all subjects tested (regression line $y=1.23 \pm$ $1.81 \mathrm{x}, \mathrm{r}=0.59, \mathrm{P}<0.001)$. The observed relationship between cAMP excretion and creatinine excretion confirms a previous report in normal subjects (Kaminsky et al, 1970). In the group of subjects aged 20-35 years the correlation between cAMP excretion and age was not significant $(P>0.5)$; on the contrary, the correlation between age and 24 hour urinary cAMP excretion in older subjects, as illustrated in fig 3 , was highly significant (regression line $y=7.175-0.068 x, r=0.66, \mathrm{P}<0.001)$. The regression slope demonstrated a progressive decrease in CAMP excretion from the age of 70 to the tenth decade.

There was a positive correlation $(\mathrm{r}=0.61, \mathrm{P}<$ 0.001 ) between cAMP excretion and body surface area (fig 4), according to the data previously reported in normal subjects (Taylor et al, 1970). No

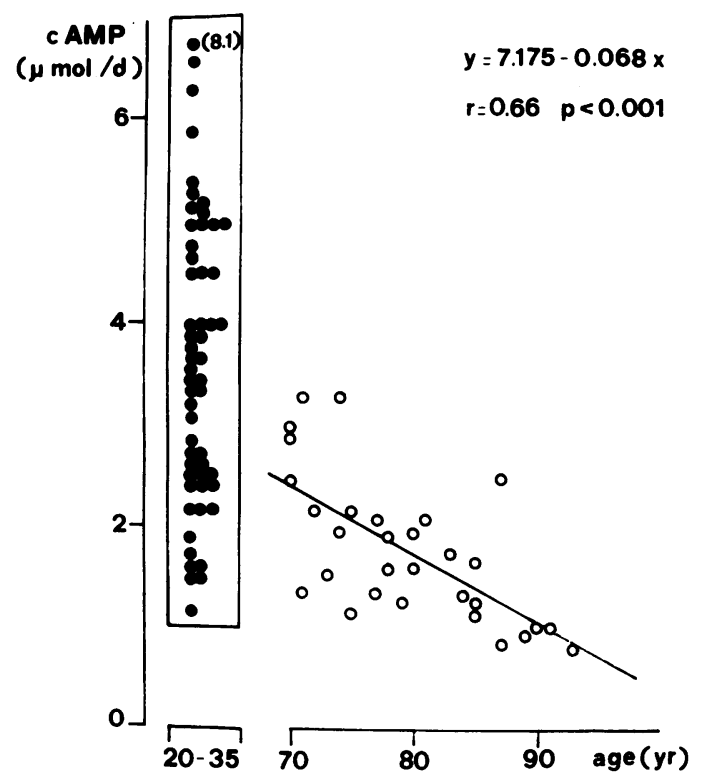

Fig 3 Relationship between urinary cAMP excretion ( $\mu$ mol/day) and age in 30 older subjects. In the group of 55 younger subjects the correlation was not significant (P $>0.5)$.

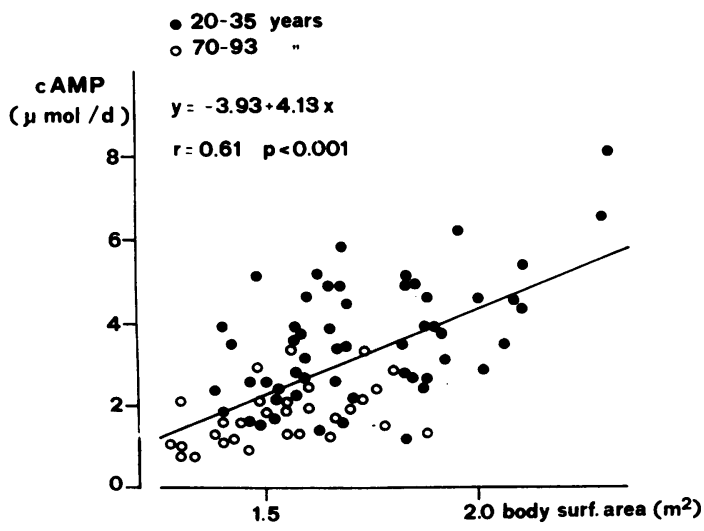

Fig 4 Plot of cAMP excretion ( $\mu$ mol/day) against the body surface area $\left(\mathrm{m}^{2}\right)$ in 55 normal young adults (20-35 yr) and in 30 elderly subjects (70-93 yr). 
significant differences in cAMP excretion in men and women were observed. Only small variations in urinary cAMP excretion from day to day were found in individual subjects.

\section{Discussion}

There seems, therefore, to be no doubt that urinary cAMP excretion falls with age in older people of both sexes. We cannot be certain what causes this decrease: cAMP in urine comes both from plasma by glomerular filtration and from renal tubular cells by leakage into the tubular fluid. Under normal conditions the urinary excretion of cAMP is largely a function of glomerular filtration (Broadus et al, 1970a), so that in normal subjects cAMP excretion is significantly correlated with creatinine excretion (Kaminsky et al, 1970); the nucleotide production in plasma may well be the result of small net contributions from many tissues. The remaining aliquot of the urinary nucleotide represents nephrogenously generated CAMP, and this nephrogenous contribution is for the most part under the control of parathyroid hormone.

Therefore, several possible mechanisms could account for the reduced urinary cAMP excretion in elderly subjects.

First, it might reflect a general decline with age in the reactivity of adenyl cyclase in response to hormonal stimulation at various cell membrane levels. Little information is available concerning the major sources (liver, kidney, and adrenals) of plasma cAMP under basal conditions. The possibility that other regions, such as adipose tissue and skeletal muscle, may contribute markedly to the circulating levels of the nucleotide cannot be excluded (Wehmann et al, 1974). A close correlation between lean body mass and urinary creatinine has previously been shown (Miller and Blyth, 1952): thus, in elderly subjects, the reduced lean body mass could be related to a decreased excretion of both cAMP and creatinine.

Secondly, the 24-hour excretion of cAMP was found to increase with exercise (Eccleston et al, 1970): a lack of activity may be one of the factors leading to the low values obtained in our older hospitalized subjects when compared to those in younger persons.

Thirdly, in normal old age nephrons become obsolescent and the glomerular filtration rate falls (Davies and Shock, 1950): the reduction in glomerular filtration rate might contribute to a decrease in the filtered load of the nucleotide. In addition, the low urinary excretion of cAMP might reflect a decline in the activity of the adenyl cyclase-cAMP system in the senile kidney. About one-third of the
cAMP excreted in the urine is produced by tubular cells (Kaminsky et al, 1970).

\section{References}

Ball, J. H., Kaminsky, N. I., Hardman, J. G., Broadus, A. E., Sutherland, E. W., and Liddle, G. W. (1972). Effects of catecholamines and adrenergic-blocking agents on plasma and urinary cyclic nucleotides in man. J. clin. Invest., 51, 2124-2129.

Broadus, A. E., Kaminsky, N. I., Hardman, I. G., Sutherland, E. W., and Liddle, G. W. (1970a). Kinetic parameters and renal clearances of plasma adenosine $3^{\prime}$, $5^{\prime}$-monophosphate and guanosine $3^{\prime}, 5^{\prime}$-monophosphate in man. J. clin. Invest., 49, 2222-2236.

Broadus, A. E., Kaminsky, N. I., Northcutt, R. C., Hardman, J. G., Sutherland, E. W., and Liddle, G. W. (1970b). Effects of glucagon on adenosine $3^{\prime}, 5^{\prime}$-monophosphate and guanosine 3', 5'-monophosphate in human plasma and urine. J. clin. Invest., 49, 2237-2245.

Butcher, R. W. and Sutherland, E. W. (1962). Adenosine 3', $5^{\prime}$-phosphate in biological materials. I. Purification and properties of cyclic $3^{\prime}, 5^{\prime}$ nucleotide phosphodiesterase and use of this enzyme to characterize adenosine $3^{\prime}, 5^{\prime}$-phosphate in human urine. J. biol. Chem., 237, 1244-1250.

Chase, L. R. and Aurbach, G. D. (1967). Parathyroid function and the renal excretion of $3^{\prime}, 5^{\prime}$-adenylic acid. Proc. nat. Acad. Sci. (Wash.), 58, 518-525.

Chase, L. R. and Aurbach, G. D. (1968). Renal adenyl cyclase: anatomically separate sites for parathyroid hormone and vasopressin. Science, 159, 545-547.

Davies, D. F. and Shock, N. W. (1950). Age changes in glomerular filtration rate, effective renal plasma flow, and tubular excretory capacity in adult males. J. clin. Invest, 29, 496-507.

Eccleston, D., Loose, R., Pullar, I. A., and Sugden, R. F. (1970). Exercise and urinary excretion of cyclic A.M.P. Lancet, 2, 612-613.

Hamet, P., Kuchel, O., and Genest, J. (1973). Effect of upright posture and isoproterenol infusion on cyclic adenosine monophosphate excretion in control subjects and patients with labile hypertension. J. clin. Endocr., 36, 218226.

Kaminsky, N. I., Broadus, A. E., Hardman, J. G., Jones, D. J., Ball, J. H., Sutherland, E. W., and Liddle, G. W. (1970). Effects of parathyroid hormone on plasma and urinary adenosine $3^{\prime}, 5^{\prime}$-monophosphate in man. J. clin. Invest., 49, 2387-2395.

Linarelli, L. G. (1972). Newborn urinary cyclic A.M.P. and developmental renal responsiveness to parathyroid hormone. Pediatrics, 50, 14-23.

Mallette, L. E., Bilezikian, J. P., Heath, D. A., and Aurbach, G. D. (1974). Primary hyperparathyroidism: clinical and biochemical features. Medicine (Baltimore), 53, 127-146.

Miller, A. T. Jr., and Blyth, C. S. (1952). Estimation of lean body mass and body fat from basal oxygen consumption and creatinine excretion. J. appl. Physiol., 5, 73-78.

Murad, F. and Pak, C. Y. C. (1972). Urinary excretion of adenosine $3^{\prime}, 5^{\prime}$-monophosphate and guanosine $3^{\prime}, 5^{\prime}$ monophosphate. New Engl. J. Med., 286, 1382-1387.

Neelon, F. A., Drezner, M., Birch, B. M., and Lebovitz, H. E. (1973). Urinary cyclic adenosine monophosphate as an aid in the diagnosis of hyperparathyroidism. Lancet, 1 , 631-634.

Takahashi, K., Kamimura, M., Shinko, T., and Tsuji, S. (1966). Effects of vasopressin and water-load on urinary adenosine-3', 5'-cy'clic monophosphate. Lancet, 2, 967.

Taylor, A. L., Davis, B. B., Pawlson, L. G., Josimovich, J. B., 
and Mintz, D. H. (1970). Factors influencing the urinary excretion of $3^{\prime}, 5^{\prime}$-adenosine monophosphate in humans. J. clin. Endocr., 30, 316-324.

Tovey, K. C., Oldham, K. G., and Whelan, J. A. M. (1974).

A simple direct assay for cyclic AMP in plasma and other biological samples using an improved competitive protein binding technique. Clin. chim. Acta, 56, 221-234.

Wehmann, R. E., Blonde, L., and Steiner, A. L. (1974).

Sources of cyclic nucleotides in plasma. J. clin. Invest., 53, 173-179.

\section{The December 1975 Issue}

\section{THE DECEMBER 1975 ISSUE CONTAINS THE FOLLOWING PAPERS}

Intracellular mucous inclusions A. I. SPRIGGS AND D. W. JERROME

Spontaneous infarction of the breast J. J. LUCEY

Extrarenal malignancy and the nephrotic syndrome J. M. HEATON, M. A. MENZIN, AND D. N. CARNEY

Quantitative observations on iliac bone marrow mast cells in chronic renal failure KATHLEEN $M$. PEART AND H. A. ELLIS

Agar culture and chromosome analysis of eoxinophilic leukaemia JOHN M. GOLDMAN, VESNA NAJFELD, AND K. H. TH'NG

Change of blood group from $A_{2}$ to $A_{x}$ in a child with congenital abnormalities G. W. G. BIRD, KEITH D. ROBERTS, AND JUNE WINGHAM

Effect of Bacteroides fragilis on the human erythrocyte membrane: pathogenesis of Tk polyagglutination G. INGLIS, G. W. G. BIRD, A. A. B. MITCHELL, G. R. MILNE, AND JUNE WINGHAM

Detection and quantitation of tetanus antitoxin in blood donations A. BARR, B. C. DOW, W. C. WATSON, AND E. HUNTER

Factor VIII levels during the course of acute hepatitis in a haemophiliac B. G. GAZZARD, R. CLARK, P. T. FLUTE, AND ROGER WILLIAMS

Heparin neutralizing activity test in the diagnosis of acute myocardial infarction J. R. O'BRIEN, M. ETHERINGTON, SANDRA JAMIESON, P. LAWFORD, JANET SUSSEX, AND S. V. LINCOLN

Laboratory contamination of blood cultures R. C. SPENCER AND M. A. SAVAGE
Comparison of tablets and paper discs for antibiotic sensitivity testing D. F. J. BROWN AND D. KOTHARI

Determination of antimicrobial MIC by paper diffusion method M. S. SHAFI

Pseudomonas putrefaciens as a cause of infection in humans J. DEBOIS, H. DEGREEF, J. VANDEPITTE, AND J. SPAEPEN

A note on the use of immunofluorescent methods for the detection of Pseudomonas aeruginosa in bronchitic sputum R. L. SANDS AND I. D. GREEN

Use of a serologically distinct strain of Thermoactinomyces vulgaris in the diagnosis of farmer's lung disease F. B. GREATOREX AND J. V. S. PETHER

Isolation of chlamydia in irradiated and nonirradiated McCoy cells L. JOHNSON AND I. A. HARPER

\section{Technical methods}

A simple test to demonstrate antibiotic synergism E. YOURASSOWSKY, M. P. VANDERLINDEN, AND E. SCHOUTENS

A modified rack for the LKB Sample Processor P. R. PANNALL, B. K. CLUR, G. M. POTGIETER, AND J. GILCHRIST

Letter to the Editor

Book reviews

Index to Volume XXVIII

Annual Contents

Copies are still available and may be obtained from the PUBLISHING MANAGER, BRITISH MEDICAL ASSOCIATION, TAVISTOCK SQUARE, LONDON, WC1H 9JR, price $£ 2.00$ 